\title{
Folic acid-targeted iron oxide nanoparticles as contrast agents for magnetic resonance imaging of human ovarian cancer
}

\author{
He Zhang ${ }^{1+}$, Jingchao $\mathrm{Li}^{2+}$, Yong $\mathrm{Hu}^{2}$, Mingwu Shen ${ }^{2}$, Xiangyang Shi ${ }^{2^{*}}$ and Guofu Zhang ${ }^{1 *}$
}

\begin{abstract}
Background: Improved methods for the early and specific detection of ovarian cancer are needed.

Methods: In this experimental study, we used folic acid (FA)-targeted iron oxide (Fe3O4) nanoparticles (NPs) as a T2-negative contrast agent for magnetic resonance (MR) imaging to accurately detect ovarian cancer tissues in an intraperitoneal xenograft tumor model. Human serous ovarian cell line (Skov-3), with overexpressed FA receptors, was chosen as the targeted tumor cell mode. For in vivo experiments, the cells were injected intraperitoneally into nude mice to produce intraabdominal ovarian cancers. FA-targeted and non-targeted $\mathrm{Fe}_{3} \mathrm{O}_{4} \mathrm{NPs}$ were prepared.

Results: FA-targeted $\mathrm{Fe}_{3} \mathrm{O}_{4} \mathrm{NPs}$ with a mean size of $9.2 \pm 1.7 \mathrm{~nm}$ have a negligible cytotoxicity to human serous ovarian cell line (Skov-3). Importantly, the results of cellular uptake suggested that $\mathrm{FA}$-targeted $\mathrm{Fe}_{3} \mathrm{O}_{4} \mathrm{NPs}$ have a targeting specificity to Skov-3 cells overexpressing FA receptors. FA-targeted $\mathrm{Fe}_{3} \mathrm{O}_{4} \mathrm{NPs}$ could be specifically localized by magnetic resonance (MR) imaging to the intraperitoneal human ovarian carcinoma tissues, as documented by a statistically significant difference $(p=0.002, n=3)$ in $T_{2}$ signal intensities of xenograft tumor tissues when injected with FA-targeted and non-targeted $\mathrm{Fe}_{3} \mathrm{O}_{4} \mathrm{NPs}$ at $4 \mathrm{~h}$ post-injection.
\end{abstract}

Conclusion: $\mathrm{FA}$-targeted $\mathrm{Fe}_{3} \mathrm{O}_{4} \mathrm{NPs}$ appear to be promising agents for the detection of human ovarian carcinoma by MR imaging, and possibly also for the hyperthermal treatment of the tumors.

Keywords: Ovarian cancer, Iron oxide nanoparticles, Folic acid, Targeting, Magnetic resonance imaging

\section{Background}

Ovarian cancer is the sixth most commonly diagnosed cancer in the world, accounting $4 \%$ of all cancers in women [1], and it is the leading cause of death from gynecologic malignancies in the western world [2, 3]. Most ovarian cancers are first diagnosed in an advanced stage because patients' symptoms may be minimal or nonspecific and no reliable biomarkers are available [4]. Tumor-debulking surgery is the first choice of management for most patients with ovarian cancer [5], but most ovarian cancers recur after surgery and are intractably drug resistant [6]. Therefore, although some advances in

\footnotetext{
*Correspondence: xshi@dhu.edu.cn; zhangguofu1018@163.com ${ }^{\dagger}$ Equal contributors

${ }^{2}$ College of Chemistry, Chemical Engineering and Biotechnology, Donghua University, Shanghai 201620, P. R. China

${ }^{1}$ Department of Radiology, Obstetrics and Gynecology Hospital, Fudan University, No.419 Fangxie Road, Shanghai 200011, P. R. China
}

cytoreductive surgery and case-effective chemotherapy have been made in the last decade, the prognosis for ovarian cancer, especially for epithelial ovarian cancer still is limited.

In most tertiary medical centers, magnetic resonance (MR) imaging is generally performed for imaging assessment of complex ovarian masses $[7,8]$ that are indeterminate on either palpation or ultrasonography because of MR's superb soft-tissue resolution and lack of radiation. The MR diagnostic criteria for ovarian malignancies are based on morphology: thick septum, vegetations, ascites, lymphadenopathy, and vividly enhancing solid component, which are features well described in numerous reports $[8,9]$. However, identification of the tumor tissues at an early stage with available imaging modalities still possesses a great challenge for both radiologists and clinicians. 
Recent advances in nanoscience and nanotechnology have enabled the development of various contrast agents for MR imaging applications, such as Gd (III)- or Mn (II)-based $\mathrm{T}_{1} \mathrm{MR}$ contrast agents $[10,11]$ and magnetic iron oxide nanoparticle $\left(\mathrm{Fe}_{3} \mathrm{O}_{4} \quad \mathrm{NPs}\right)$-based $\mathrm{T}_{2} \mathrm{MR}$ contrast agents [12-14]. The $\mathrm{Fe}_{3} \mathrm{O}_{4}$ NPs are the most commonly used magnetic materials for various biomedical applications [15-18]. But, few reports on the application of $\mathrm{Fe}_{3} \mathrm{O}_{4}$ NPs for the diagnosis of ovarian cancer have been published.

Folic acid (FA) receptors as single-chain glycoproteins with high specific affinity for FA are highly overexpressed on various malignant tumors, including human ovarian cancer [19]. The over-expression of FA receptors on malignant tumor tissues can be exploited as a specific targeting ligand since most healthy tissues have little FA receptors expression [20]. This targeting strategy has the potential for diagnostic and therapeutic application in a wide variety of cancers [21, 22].

In this research, we used FA-targeted $\mathrm{Fe}_{3} \mathrm{O}_{4} \mathrm{NPs}$ as $\mathrm{T}_{2}$-negative contrast agents for in vivo $\mathrm{MR}$ imaging of ovarian cancer in an intraperitoneal xenograft tumor model. To the best of our knowledge, this is the first reported application of FA-targeted $\mathrm{Fe}_{3} \mathrm{O}_{4}$ NPs in MR imaging diagnosis of ovarian cancer.

\section{Methods}

\section{Synthesis and characterization techniques}

FA-targeted $\mathrm{Fe}_{3} \mathrm{O}_{4}$ NPs were synthesized and characterized according to our previous work [23]. Non-targeted $\mathrm{Fe}_{3} \mathrm{O}_{4}$ NPs were synthesized by the same methods, except for the use of $m$ PEG-COOH in the PEGylation step instead of FA-PEG-COOH.

Branched polyethyleneimine (PEI, $\mathrm{Mw}=25,000$ ) -coated $\mathrm{Fe}_{3} \mathrm{O}_{4}$ NPs $\left(\mathrm{Fe}_{3} \mathrm{O}_{4} @ P E I\right.$ NPs) were synthesized via a reduction route. $\mathrm{FeCl}_{3} \cdot 6 \mathrm{H}_{2} \mathrm{O}(1.3 \mathrm{~g})$ was dissolved in $20 \mathrm{~mL}$ water, and placed into a $250 \mathrm{~mL}$ three-necked flask. Under vigorous stirring, the solution was bubbled with nitrogen atmosphere for $15 \mathrm{~min}$, then $10 \mathrm{~mL}$ freshly prepared sodium sulfite solution $(0.2 \mathrm{~g})$ was added slowly into the flask. $30 \mathrm{~min}$ later, $5 \mathrm{~mL}$ PEI $(0.5 \mathrm{~g})$ and $2 \mathrm{~mL}$ ammonia $(25 \%)$ was added into the flask successively. The reaction mixture was vigorously stirred for $30 \mathrm{~min}$ at $60 \sim 70{ }^{\circ} \mathrm{C}$, and then at room temperature for another $1.5 \mathrm{~h}$. The product $\left(\mathrm{Fe}_{3} \mathrm{O}_{4} @ P E I\right.$ NPs $)$ was magnetically collected and washed 3 times with water. Finally, the sample was centrifuged ( $8000 \mathrm{rpm}, 10 \mathrm{~min}$ ) to remove the aggregation and larger particles.

An aqueous solution of $\mathrm{Fe}_{3} \mathrm{O}_{4} @$ PEI NPs (110 mg, $35 \mathrm{~mL}$ ) was precipitated by virtue of an external magnet and re-dispersed in $20 \mathrm{~mL}$ DMSO. Another solution of $38.5 \mathrm{mg}$ activated FA-PEG-COOH or $\mathrm{mPEG}-\mathrm{COOH}$ in $2 \mathrm{~mL}$ DMSO was added dropwise into the above DMSO solution of $\mathrm{Fe}_{3} \mathrm{O}_{4} @$ PEI NPs and kept shaking for $3 \mathrm{~d}$.
The formed products were collected by magnetic separation and washed with DMSO for 3 times to remove excess reactants. Finally, the amino groups on the surface of the particles were acetylated by reaction with acetic anhydride. Briefly, triethylamine $(493 \mu \mathrm{L})$ was added into the aqueous solution of raw product of $\mathrm{Fe}_{3} \mathrm{O}_{4} @$ PEI-PEG-FA NPs or $\mathrm{Fe}_{3} \mathrm{O}_{4} @ P E I-m$ PEG NPs under vigorous shaking using a shaker at room temperature. After $30 \mathrm{~min}$, acetic anhydride $(402 \mu \mathrm{L})$ was dropwise added into the above mixture solution and the reaction was continued for $1 \mathrm{~d}$. After several times magnetic separation/washing/dispersion steps to remove excess reactants and by-products, the final products (FA-targeted $\mathrm{Fe}_{3} \mathrm{O}_{4}$ NPs and non-targeted $\mathrm{Fe}_{3} \mathrm{O}_{4} \mathrm{NPs}$ ) were obtained, re-dispersed in water and stored under $4{ }^{\circ} \mathrm{C}$ for further use.

A JEOL 2010 F transmission electron microscopy (TEM, JEOL, Tokyo, Japan) was used to characterize the morphology of the FA-targeted $\mathrm{Fe}_{3} \mathrm{O}_{4}$ NPs and nontargeted $\mathrm{Fe}_{3} \mathrm{O}_{4}$ NPs at an operating voltage of $200 \mathrm{kV}$. A dilute particle suspension of the sample in water $(10 \mu \mathrm{L})$ was deposited onto a carbon-coated copper grid and dried in air before measurements. The effect of MR imaging for FA-targeted and non-targeted $\mathrm{Fe}_{3} \mathrm{O}_{4} \mathrm{NPs}$ was evaluated with a 1.5 Tesla MR imaging machine (Siemens Avanto, Erlangen, Germany). Samples were diluted with water to have different $\mathrm{Fe}$ concentrations in the range of 0.005$0.08 \mathrm{mM}$ before measurements. The $\mathrm{T}_{2}$-weighted imaging parameters with turbo spin echo sequence were set as follows: point resolution $=156 \mathrm{~mm} \times 156 \mathrm{~mm}$, section thickness $=1.5 \mathrm{~mm}, \mathrm{TR}=4000 \mathrm{~ms}, \mathrm{TE}=85 \mathrm{~ms}$, bandwidth $(\mathrm{Hz})=260$, number of excitation $=1$, and voxel size $=1.1 \times 1.1 \times 4.0 \mathrm{~mm}$.

\section{Cell culture}

Skov-3 cells was obtained from the Shanghai Key Laboratory of Female Reproductive Endocrine Related Diseases (Shanghai, China). Skov-3 cells were grown in FA-free RPMI-1640 medium supplemented with $10 \%$ fetal bovine serum (FBS), penicillin $(100 \mathrm{U} / \mathrm{mL})$ and streptomycin $(100 \mu \mathrm{g} / \mathrm{mL})$ at $37{ }^{\circ} \mathrm{C}$ and $5 \% \mathrm{CO}_{2}$.

\section{Cytotoxicity of FA-targeted $\mathrm{Fe}_{3} \mathrm{O}_{4} \mathrm{NPs}$ and non-targeted $\mathrm{Fe}_{3} \mathrm{O}_{4} \mathrm{NPs}$}

The 3-(4,5-dimethylthiazol-2-yl)-2,5-diphenyltetrazolium bromide (MTT) viability assay was carried out to evaluate the cytotoxicity of the FA-targeted $\mathrm{Fe}_{3} \mathrm{O}_{4}$ NPs and non-targeted $\mathrm{Fe}_{3} \mathrm{O}_{4}$ NPs. Briefly, $1 \times 10^{4}$ Skov- 3 cells were seeded into each well of 96-well cell culture plates with $200 \mu \mathrm{L}$ regular RPMI-1640 medium and cultured at $37{ }^{\circ} \mathrm{C}$ and $5 \% \mathrm{CO}_{2}$ overnight to bring the cells to confluence. Next, the medium in each well was discarded carefully and $200 \mu \mathrm{L}$ of fresh medium containing phosphate-buffered saline (PBS), FA-targeted $\mathrm{Fe}_{3} \mathrm{O}_{4} \mathrm{NPs}$ 
or non-targeted $\mathrm{Fe}_{3} \mathrm{O}_{4} \mathrm{NPs}$ at the $\mathrm{Fe}$ concentration of 0.5 to $1.0 \mathrm{mM}$ was added. After $24 \mathrm{~h}$ incubation at $37^{\circ} \mathrm{C}$ and $5 \% \mathrm{CO}_{2}, 20 \mu \mathrm{L}$ MTT solution $(5 \mathrm{mg} / \mathrm{mL}$ in PBS buffer) were added to each well to reveal the viable cells. After further incubation for $4 \mathrm{~h}$ at $37{ }^{\circ} \mathrm{C}$ and $5 \% \mathrm{CO}_{2}$, the medium was carefully removed, and DMSO $(200 \mu \mathrm{L})$ was added to dissolve the formazan grains. The absorbance value of each well was measured with a microplate reader at $450 \mathrm{~nm}$ wavelength.

\section{Cellular uptake of FA-targeted $\mathrm{Fe}_{3} \mathrm{O}_{4}$ NPs and non-targeted $\mathrm{Fe}_{3} \mathrm{O}_{4} \mathrm{NPs}$}

To qualitatively confirm the cellular uptake of $\mathrm{Fe}_{3} \mathrm{O}_{4}$ NPs by Skov-3 cells, the cells was stained with Prussian blue. In brief, $5 \times 10^{5}$ cells were seeded into each well of 24-well cell culture plates. After overnight incubation at $37{ }^{\circ} \mathrm{C}$ and $5 \% \mathrm{CO}_{2}$ to bring the cells to $80 \%$ confluence, the medium was replaced with fresh medium containing PBS buffer (control), FA-targeted $\mathrm{Fe}_{3} \mathrm{O}_{4}$ NPs, or nontargeted $\mathrm{Fe}_{3} \mathrm{O}_{4} \mathrm{NPs}$ at the Fe concentrations of 0.2 and $0.4 \mathrm{mM}$. The cells were continuously incubated for another $4 \mathrm{~h}$. The cells were then washed three times with PBS, fixed with p-formaldehyde solution at $4{ }^{\circ} \mathrm{C}$ for $15 \mathrm{~min}$, and stained with Prussian blue reagent (potassium ferrocyanide $[1 \mathrm{~g}]$ dissolved in water [9 mL] mixed with $36-38 \% \mathrm{HCl}$ [1 mL]) at $37^{\circ} \mathrm{C}$ for $30 \mathrm{~min}$. The cells were imaged with a Leica DMIL LED inverted-phase contrast microscope.

The Leeman Prodigy inductively coupled plasma-optical emission spectroscopy (ICP-OES, Hudson, NH, USA) also was used to quantify the cellular uptake of the $\mathrm{Fe}_{3} \mathrm{O}_{4}$ NPs by Skov-3 cells. The Skov- 3 cells were seeded into 12 -well plates with a density of $1 \times 10^{6}$ cells/well. After overnight incubation to bring the cells to confluence, the medium was discarded carefully, and $1 \mathrm{~mL}$ fresh medium containing PBS buffer (control), FA-targeted $\mathrm{Fe}_{3} \mathrm{O}_{4}$ NPs or nontargeted $\mathrm{Fe}_{3} \mathrm{O}_{4} \mathrm{NPs}$ at $\mathrm{Fe}$ concentrations of 0.2 and $0.4 \mathrm{mM}$ was added. The cells were further incubated at $37{ }^{\circ} \mathrm{C}$ and $5 \% \mathrm{CO}_{2}$ for $4 \mathrm{~h}$. The medium was then removed. The cells were washed with PBS buffer four times, trypsinsized, collected, and suspended in $1 \mathrm{~mL}$ PBS buffer. The cell numbers in each sample were estimated with a hemocytometer. For the cellular uptake assay, the cells were centrifuged (1000 rpm, $5 \mathrm{~min}$ ), collected, and lysed with an aqua regia solution $(0.5 \mathrm{~mL})$ for $12 \mathrm{~h}$. The Fe content was determined by ICP-OES after the samples were diluted 2 times with PBS.

\section{In vivo targeted MR imaging of tumors}

Four-week-old female BALB/c nude mice (Shanghai Cancer Institute, Shanghai, China) were treated according to protocols approved by the Ethical Committee of Obstetrics and Gynecology Hospital ([2007]-No. 6), Fudan University. The nude mice (three mice in each group) were injected intraperitoneally with $1 \times 10^{6}$ Skov-3 cells/ mouse at a site $1 \mathrm{~cm}$ left of the midline. Two weeks later, the mice were anesthetized with an intraperitoneal injection of pentobarbital sodium $(40 \mathrm{mg} / \mathrm{kg})$. After that, $200 \mu \mathrm{L}$ of FA-targeted $\mathrm{Fe}_{3} \mathrm{O}_{4}$ NPs or non-targeted $\mathrm{Fe}_{3} \mathrm{O}_{4}$ NPs $(0.6 \mathrm{mg} \mathrm{Fe})$ were delivered into the mice via the tail vein. MR scans were performed before injection and $0.5,1,2$, and $4 \mathrm{~h}$ after injection of the particles. A $1.5 \mathrm{~T}$ clinical MR system was used with a custom-built rodent receiver coil (Chenguang Med Tech, Shanghai, China). The sequence parameters were set as following: Axial fat-suppressed T2WI (FS T2WI), point resolution = $156 \mathrm{~mm} \times 156 \mathrm{~mm}$, TR/TE: 8000/83 ms, thickness: $2 \mathrm{~mm}$, field of view: $50 \mathrm{~mm}$, voxel size: $1.4 \times 1.4 \times 1.9 \mathrm{~mm}$, flip angles: $150^{\circ}$. Signal intensity in the tumors at each time point was measured and recorded.

\section{Statistical analysis}

Quantitative data were expressed as mean \pm standard deviation (SD). Means were compared by use of unpaired two-sided Student's $t$-test. The data are indicated with ${ }^{(*)}$ for $p<0.05$, (**) for $p<0.01$ and $\left(^{* * *}\right)$ for $p<0.001$.

\section{Results}

\section{Synthesis and characterization techniques}

The morphology of the FA-targeted $\mathrm{Fe}_{3} \mathrm{O}_{4}$ NPs and nontargeted $\mathrm{Fe}_{3} \mathrm{O}_{4}$ NPs was characterized by TEM (Fig. 1). It can be seen that the NPs with a spherical or quasispherical shape have a quite uniform size distribution and a polymer shell on their outer surface. The mean size was measured to be $8.7 \pm 1.9 \mathrm{~nm}$ for non-targeted $\mathrm{Fe}_{3} \mathrm{O}_{4} \mathrm{NPs}$ (Fig. 1a) and $9.2 \pm 1.7 \mathrm{~nm}$ for FA-targeted $\mathrm{Fe}_{3} \mathrm{O}_{4}$ NPs (Fig. 1b), respectively. The $\mathrm{T}_{2}$-weighted $\mathrm{MR}$ effect of the NPs was evaluated by use of a $1.5 \mathrm{~T}$ MR system. $\mathrm{Fe}_{3} \mathrm{O}_{4}$ NPs decreased the MR signal intensity in relation to increasing $\mathrm{Fe}$ concentration for both FA-targeted $\mathrm{Fe}_{3} \mathrm{O}_{4}$ NPs and non-targeted $\mathrm{Fe}_{3} \mathrm{O}_{4}$ NPs (Fig. 2). The $\mathrm{T}_{2}$ signal intensities of FA-targeted $\mathrm{Fe}_{3} \mathrm{O}_{4} \mathrm{NPs}$ at the given $\mathrm{Fe}$ concentrations were $1851 \pm 14,1808 \pm 18,1648 \pm 30$, $1628 \pm 71$, and $1395 \pm 73$. The $T_{2}$ signal values in nontargeted $\mathrm{Fe}_{3} \mathrm{O}_{4}$ NPs at each given Fe concentration were $2094 \pm 28,1838 \pm 14,1742 \pm 10,1667 \pm 2$ and $1487 \pm 26$, respectively (Fig. 3 ). Based on the measured $\mathrm{T}_{2}$ relaxation time, the $\mathrm{r}_{2}$ relaxivity of FA-targeted $\mathrm{Fe}_{3} \mathrm{O}_{4}$ NPs and non-targeted $\mathrm{Fe}_{3} \mathrm{O}_{4}$ NPs was calculated to be 475.92 and $545.70 \mathrm{mM}^{-1} \mathrm{~s}^{-1}$, respectively according to our previous works [23].

\section{Cytotoxicity assay of FA-targeted $\mathrm{Fe}_{3} \mathrm{O}_{4} \mathrm{NPs}$ and non-targeted $\mathrm{Fe}_{3} \mathrm{O}_{4} \mathrm{NPs}$}

It is important to assess the potential cytotoxicity of $\mathrm{Fe}_{3} \mathrm{O}_{4}$ NPs before their biomedical applications. After incubation of Skov-3 cells with FA-targeted $\mathrm{Fe}_{3} \mathrm{O}_{4}$ NPs or non-targeted $\mathrm{Fe}_{3} \mathrm{O}_{4} \mathrm{NPs}$ at the Fe concentrations of $0.25,0.50,0.75$ or $1.00 \mathrm{mM}$ for $24 \mathrm{~h}$, cell viability was 

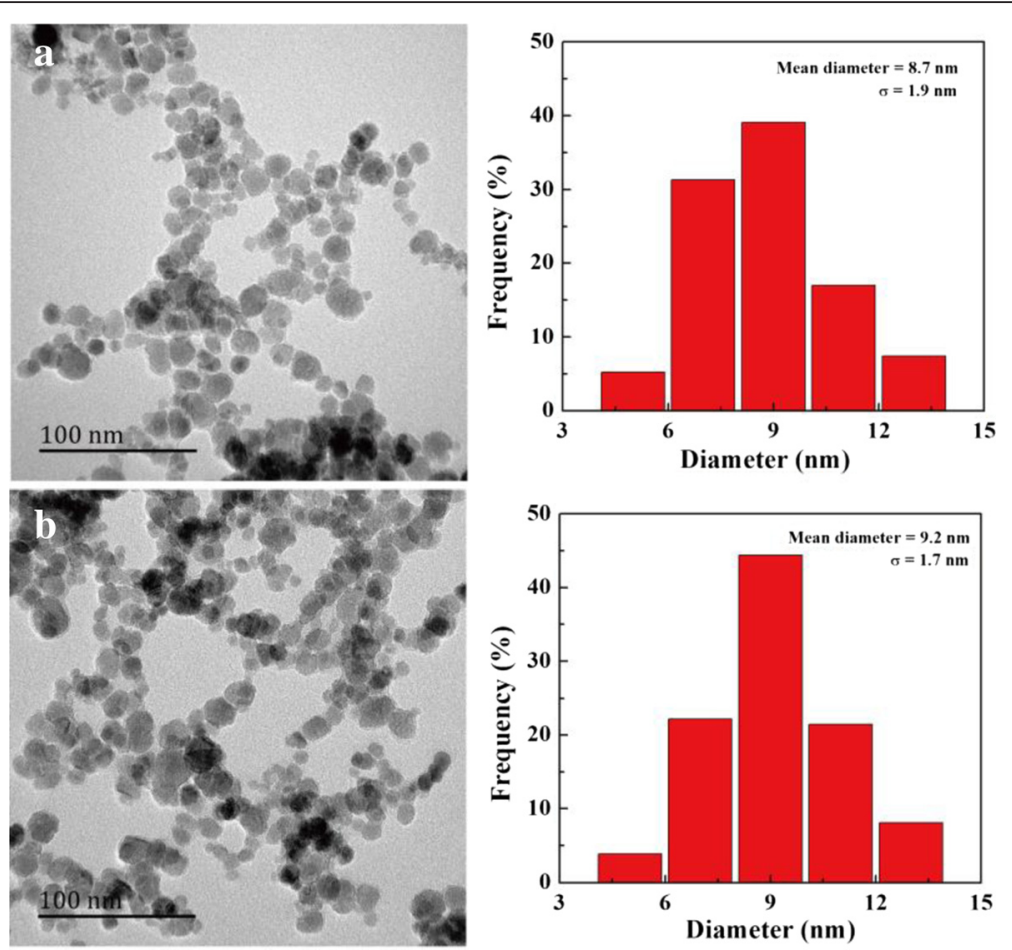

Fig. 1 TEM micrographs and size distribution histograms of non-targeted $\mathrm{Fe}_{3} \mathrm{O}_{4} \mathrm{NPs}(\mathbf{a})$ and FA-targeted $\mathrm{Fe}_{3} \mathrm{O}_{4} \mathrm{NPs}(\mathbf{b})$

assessed with the MTT assay (Fig. 4). The cell viability did not change significantly after treatment with either kind of $\mathrm{Fe}_{3} \mathrm{O}_{4}$ in the studied concentration range when compared with cell viability of control cells treated with PBS $(n=3)$. The results of MTT assay indicated the low cytotoxicity of the prepared $\mathrm{Fe}_{3} \mathrm{O}_{4} \mathrm{NPs}$, which is very important for their further in vivo applications.

\section{Cellular uptake of FA-targeted $\mathrm{Fe}_{3} \mathrm{O}_{4} \mathrm{NPs}$ and non-targeted} $\mathrm{Fe}_{3} \mathrm{O}_{4} \mathrm{NPs}$

Prussian blue staining was carried out to assess the cellular uptake of FA-targeted $\mathrm{Fe}_{3} \mathrm{O}_{4}$ NPs and non-targeted $\mathrm{Fe}_{3} \mathrm{O}_{4}$ NPs by Skov-3 cells. The results showed that the uptake of iron component correlated directly with Fe concentration, and the cells appeared dark blue compared with the control cells (Fig. 5). The Prussian blue staining also demonstrated that Skov-3 cells treated with FA-targeted $\mathrm{Fe}_{3} \mathrm{O}_{4}$ NPs had more obvious blue staining

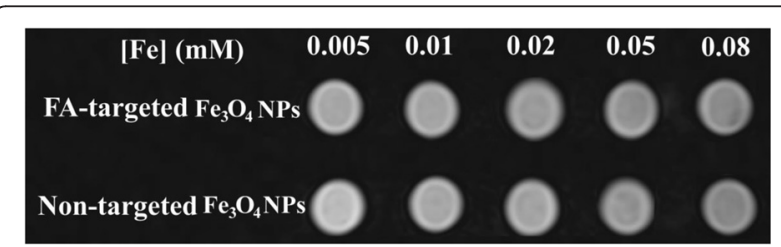

Fig. 2 The $\mathrm{T}_{2}$-weighted MR images of the FA-targeted $\mathrm{Fe}_{3} \mathrm{O}_{4} \mathrm{NPS}$ and non-targeted $\mathrm{Fe}_{3} \mathrm{O}_{4} \mathrm{NPs}$ at different Fe concentrations than the cells treated with non-targeted $\mathrm{Fe}_{3} \mathrm{O}_{4}$ NPs at the same Fe concentration. We interpreted these results as evidence that the FA-targeted $\mathrm{Fe}_{3} \mathrm{O}_{4} \mathrm{NPs}$ had a higher affinity to Skov-3 cells than the non-targeted $\mathrm{Fe}_{3} \mathrm{O}_{4}$ NPs.

To further document that FA could facilitate the specific uptake of FA-targeted $\mathrm{Fe}_{3} \mathrm{O}_{4}$ NPs by Skov-3 cells, the cells were incubated with FA-targeted $\mathrm{Fe}_{3} \mathrm{O}_{4}$ NPs or non-targeted $\mathrm{Fe}_{3} \mathrm{O}_{4}$ NPs at the Fe concentrations of 0.2

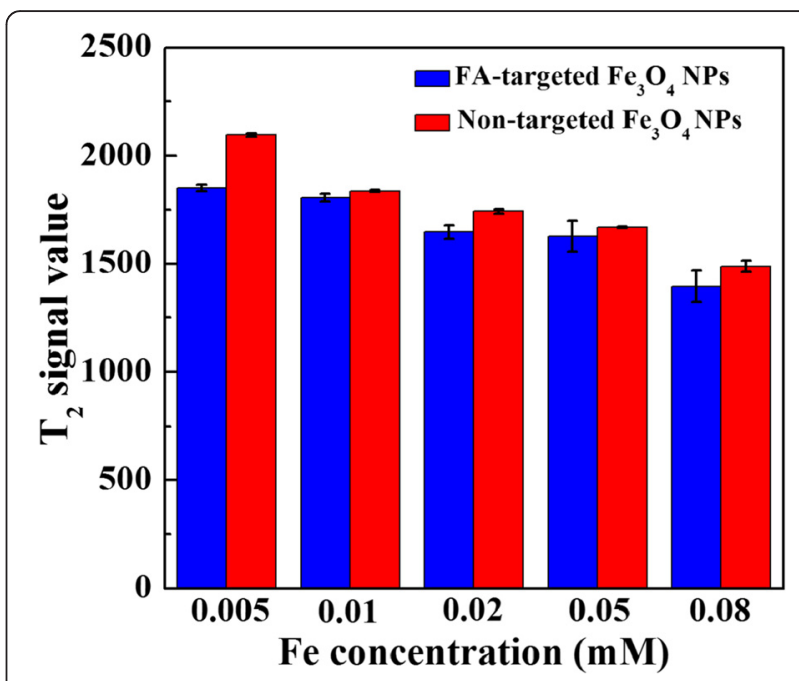

Fig. 3 The $T_{2}$ signal values of the $\mathrm{FA}$-targeted $\mathrm{Fe}_{3} \mathrm{O}_{4} \mathrm{NPs}$ and non-targeted $\mathrm{Fe}_{3} \mathrm{O}_{4}$ NPS at different Fe concentrations 


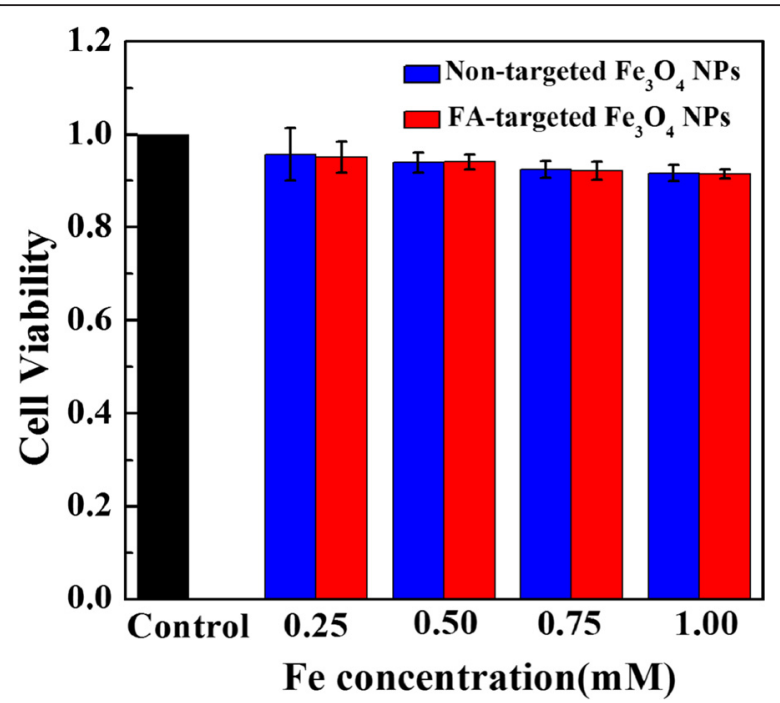

Fig. $4 \mathrm{MTT}$ assay of Skov-3 cell viability after treatment with PBS (control) and the FA-targeted $\mathrm{Fe}_{3} \mathrm{O}_{4}$ NPs or non-targeted $\mathrm{Fe}_{3} \mathrm{O}_{4} \mathrm{NPS}$ at the Fe concentration of $0.25-1.00 \mathrm{mM}$ for $24 \mathrm{~h}$

and $0.4 \mathrm{mM}$ for $4 \mathrm{~h}$. Then the Fe concentration in the cells was analyzed by ICP-OES. As shown in Fig. 6, the cellular uptake increased as a function of Fe concentration for both $\mathrm{Fe}_{3} \mathrm{O}_{4}$ NPs. At the same Fe concentration, the Skov-3 cells treated with FA-targeted $\mathrm{Fe}_{3} \mathrm{O}_{4}$ NPs displayed much higher uptake than those treated with non-targeted $\mathrm{Fe}_{3} \mathrm{O}_{4}$ NPs $(n=3)$. These results indicated that the FA-targeted $\mathrm{Fe}_{3} \mathrm{O}_{4}$ NPs can be specifically taken up by the Skov-3 cells overexpressing FA receptors via ligand-mediated endocytosis pathway.

\section{In vivo targeted MR imaging}

After intravenous injection of the FA-targeted $\mathrm{Fe}_{3} \mathrm{O}_{4}$ NPs or non-targeted $\mathrm{Fe}_{3} \mathrm{O}_{4}$ NPs into the mice bearing intraperitoneal ovarian tumors, MR scanning was performed. The tumor MR signal for the mice injected with both particles gradually decreased with time after injection (Fig. 7). In the MR images, we can see the contrast enhancement was highest at $2 \mathrm{~h}$ post injection. After that, the tumor signal recovered because of further metabolism. Quantitative analysis of the $T_{2}$ signal intensity of solid tumors at various time points revealed that the lowest signal intensity occurred at $2 \mathrm{~h}$ after injection with both the FAtargeted $\mathrm{Fe}_{3} \mathrm{O}_{4}$ NPs and non-target $\mathrm{Fe}_{3} \mathrm{O}_{4}$ NPs (Fig. 8). The $\mathrm{T}_{2}$-weighted signal intensity of the lesions at $0.5,1,2$, and $4 \mathrm{~h}$ post injection was $1666 \pm 152,1534 \pm 92,749 \pm 56$ and $1402 \pm 102$ for the FA-targeted $\mathrm{Fe}_{3} \mathrm{O}_{4}$ NPs group and $1414 \pm 42,1328 \pm 162,1181 \pm 93$ and $1615 \pm 84$ for the non-targeted $\mathrm{Fe}_{3} \mathrm{O}_{4}$ NPs group, respectively (Fig. 8). It should be noted that the $\mathrm{T}_{2}$ signals intensity of the mice treated with FA-targeted $\mathrm{Fe}_{3} \mathrm{O}_{4}$ NPs was significantly lower than that of the mice treated with non-targeted $\mathrm{Fe}_{3} \mathrm{O}_{4} \mathrm{NPs}$ at $2 \mathrm{~h}$ post injection $(P=0.002, n=3)$. This results suggested that the prepared FA-targeted $\mathrm{Fe}_{3} \mathrm{O}_{4}$ NPs have a great potential to be used as contrast agents for targeted MR imaging to diagnosis the ovarian tumors.

\section{Discussion}

In this study, we report our preliminary experience in imaging human ovarian cancer in the xenograft tumor model by using FA-targeted $\mathrm{Fe}_{3} \mathrm{O}_{4}$ NPs as contrast agents. Owing to the good contrast enhancement and low cytotoxicity, the FA-targeted $\mathrm{Fe}_{3} \mathrm{O}_{4}$ NPs can detect the ovarian cancer tissues planted in the abdominal cavity of nude mice at in vivo levels. Our results indicated that FA-targeted $\mathrm{Fe}_{3} \mathrm{O}_{4}$ NPs hold promise for being effective magnetic molecular probes for detecting tumor tissues in gynecologic cancer.

Ovarian cancer is the most malignant gynecological tumor and therefore deserves extensive basic and clinical research in the quest for early diagnostic tests and

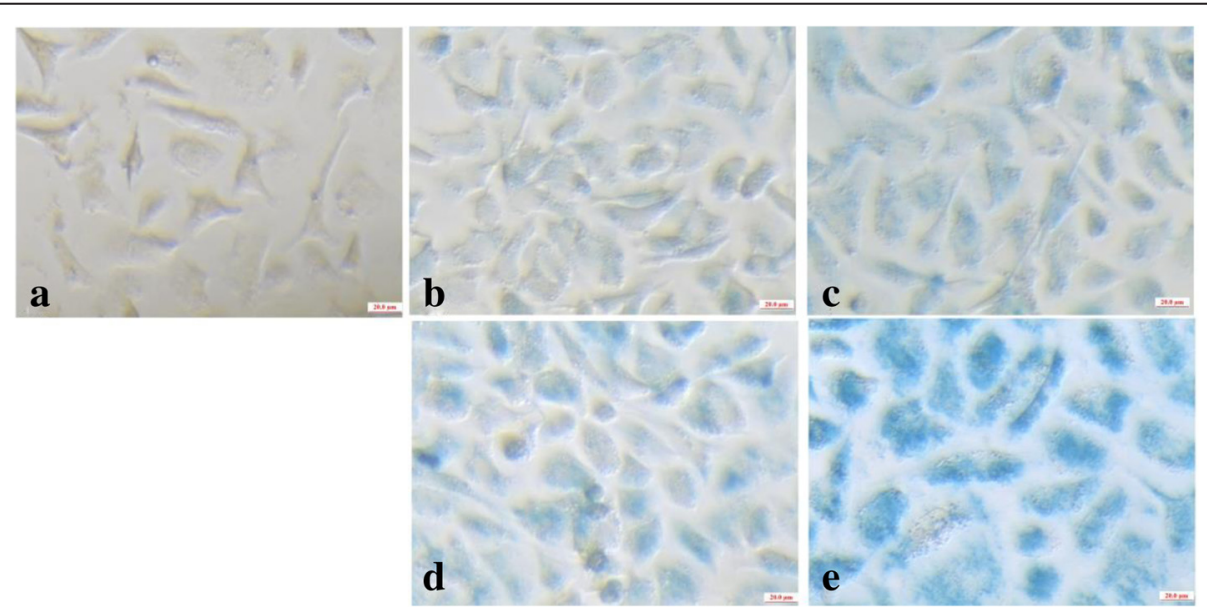

Fig. 5 Prussian blue-stained Skov3 cells incubated with PBS (a), non-targeted $\mathrm{Fe}_{3} \mathrm{O}_{4} \mathrm{NPS}_{(\mathbf{b}}$, c) and FA-targeted Fe $\mathrm{O}_{4} \mathrm{NPs}(\mathbf{d}$, e) in given Fe concentration of $0.2 \mathrm{mM}(\mathbf{b}, \mathbf{d})$ and $0.4 \mathrm{mM}(\mathbf{c}, \mathbf{f})$. Scale bar $=20 \mu \mathrm{m}$ 


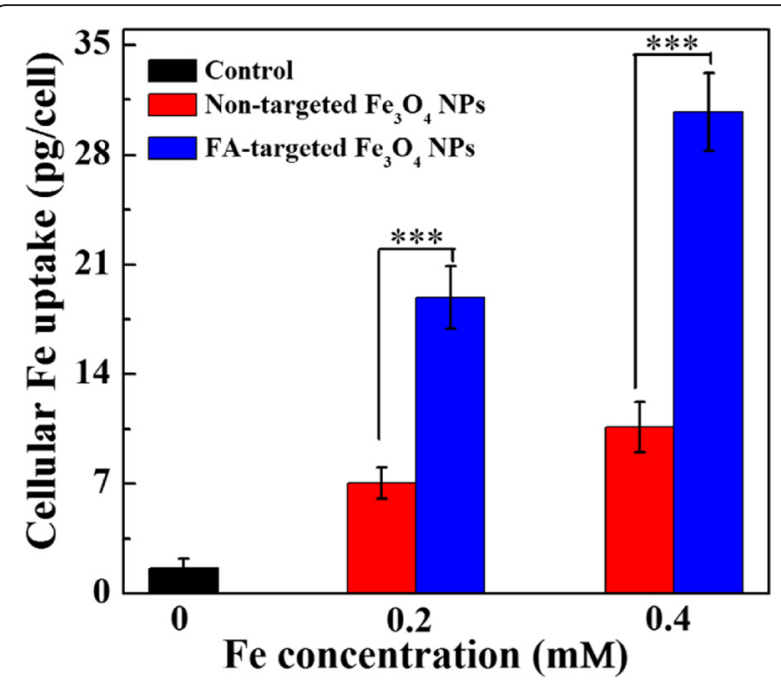

Fig. 6 Cellular uptake assay of the Skov3 cells after treatment with FA-targeted $\mathrm{Fe}_{3} \mathrm{O}_{4}$ NPs or non-targeted $\mathrm{Fe}_{3} \mathrm{O}_{4}$ NPs at Fe concentration of 0.2 and $0.4 \mathrm{mM}$

effective treatments [24-27]. $\mathrm{Fe}_{3} \mathrm{O}_{4}$ NPs are low-toxic and eventually biodegrade to form blood hemoglobin [14], and they have been used for liver imaging since the 1900 s [28]. With recent advances in nanotechnology and nanoscience [29-32], various polymers have been coated onto the surface of $\mathrm{Fe}_{3} \mathrm{O}_{4}$ NPs to improve their stability and decrease their uptake by the reticuloendothelial system [16, 33, 34]. Numerous studies on application of NPs in biomedical imaging have been reported in recent decades [35-40], but few have examined application of the particles in ovarian cancer.

In our previous work, we demonstrated that FA-targeted $\mathrm{Fe}_{3} \mathrm{O}_{4}$ NPs have good water-dispersibility, colloidal stability and fairly high relaxivity [23]. In addition, the particles have excellent hemocompatibility and cytocompatibility in the studied range of concentrations. We found that FAtargeted $\mathrm{Fe}_{3} \mathrm{O}_{4}$ NPs had excellent binding specificity to a human cervical cancer cell line (HeLa cells) overexpressing FA receptors via an active FA targeting pathway. In the present study, we found excellent lesion targeting ability of the FA-targeted $\mathrm{Fe}_{3} \mathrm{O}_{4}$ NPs to ovarian cancer in the $\mathrm{T}_{2}$-weighted $\mathrm{MR}$ imaging, which may be attributed to

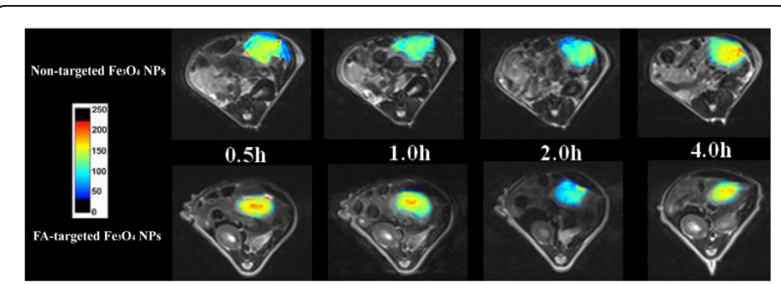

Fig. 7 In vivo MR imaging of intraperitoneal tumor after intravenous injection of FA-targeted $\mathrm{Fe}_{3} \mathrm{O}_{4}$ NPs or non-targeted $\mathrm{Fe}_{3} \mathrm{O}_{4} \mathrm{NPS}$ (0.6 $\mathrm{mg} \mathrm{Fe}$ ) at different time points

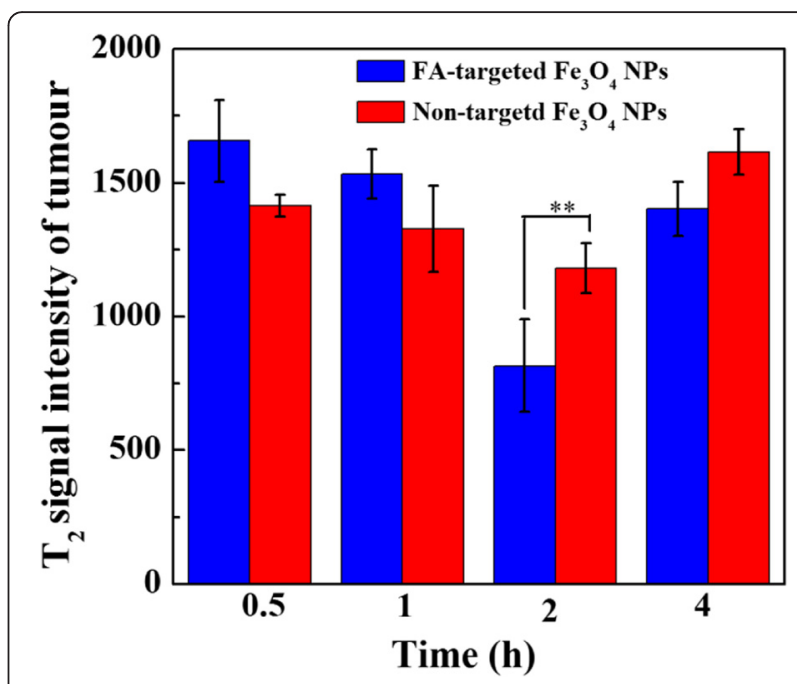

Fig. 8 Measurements of $T_{2}$ signals intensity of intraperitoneal tumor in nude mice after intravenous injection of FA-targeted $\mathrm{Fe}_{3} \mathrm{O}_{4} \mathrm{NPs}$ or non-targeted $\mathrm{Fe}_{3} \mathrm{O}_{4}$ NPs (0.6 mg Fe) at different time points

the following aspects: First, although the mean size of the FA-targeted $\mathrm{Fe}_{3} \mathrm{O}_{4}$ NPs was small $(9.2 \pm 1.7 \mathrm{~nm})$, the particles had a very high $r_{2}$ relaxivity coefficients $(475.92 \mathrm{mM}$ ${ }^{-1} \mathrm{~s}^{-1}$ ), which is much higher than those of other reported $\mathrm{Fe}_{3} \mathrm{O}_{4}$ NPs $[33,40]$. This feature made the particles more sensitive to magnetic susceptibility effects. Second, the presence of FA on the surface of the $\mathrm{Fe}_{3} \mathrm{O}_{4}$ NPs increased their ability to target tumor tissues. Third, the passive enhanced permeability and retention effect into solid tumors may also facilitate the specific MR imaging of tumors [36].

Human ovarian cancers are located deep in the pelvic space [41]. An ideal humanized xenograft mouse model of ovarian cancer would simulate the true microenvironment for tumor angiogenesis [24, 42-44]. Thus, in the present study, we implanted the tumor cells in the abdomen rather than in subcutaneous sites, believing that the intraperitoneal location would reflect the hemodynamic condition of ovarian cancer in humans-at least more accurately than would a subcutaneous site, as has been often used [10-12, 25]. Our results corroborated this point: both targeted and non-targeted particles were evident by $\mathrm{T}_{2}$-weithted $\mathrm{MR}$ imaging at $2 \mathrm{~h}$ after injection in abdominal tumors compared with $1 \mathrm{~h}$ in subcutaneous tumors [23], perhaps because more time was needed for $\mathrm{Fe}_{3} \mathrm{O}_{4}$ NPs to reach the deep abdominal tumors in sufficient concentration to be evident on $\mathrm{T}_{2}$-enhanced imaging. We must confess that the $\mathrm{T}_{2}$ signal intensity in MR images also achieve the lowest point at $2 \mathrm{~h}$ post injection of non-targeted $\mathrm{Fe}_{3} \mathrm{O}_{4} \mathrm{NPs}$, which may be due to the enhanced permeability and retention (EPR) effect (passive uptake) as well documented in solid tumors $[14,36,37]$. However, both in vitro and in vivo imaging results (as shown in Figs. 5 and. 7) proved FA-targeted 
ligands can enable the tumor uptake through more active pathway, thus making the tumors look like more dark compared with non-FA targeted group.

Further, we also found that, after injection of $\mathrm{Fe}_{3} \mathrm{O}_{4} \mathrm{NPs}$ in the nude mice, the tumor $\mathrm{T}_{2}$ signal intensity had reverted to pre-injection intensity after $4 \mathrm{~h}$, a little earlier than that we had found previously in subcutaneous tumors [23]. We also acknowledge that the injection of suspensions of tumor cells into the mice is different from the formation of tumors in the natural environment.

Other methods for imaging detection of ovarian cancers have been described. Hensley, et al [45] described a dual MR-fluorescence molecular tomography approach, with commercially available fluorescent molecular imaging probes for the detection and quantification of tumorassociated metabolites in ovarian carcinomas in a transgenic mouse model of epithelial ovarian cancer. The authors concluded that the combination of in vivo molecular and MR imaging can effectively detect orthotopic ovarian tumors and their response to therapy [25]. In another study, Satpathy, et al [24] reported that in an orthotopic human ovarian tumor xenograft model, HER2- targeted magnetic NPs labeled with a near infrared dye (NIR-830) were specifically delivered into primary and disseminated ovarian tumors, enabling optical and MR imaging of tumors as small as $1 \mathrm{~mm}$ in the peritoneal cavity. The authors designed the non-conjugated magnetic NPs with $14 \pm 3.4 \mathrm{~nm}$ diameter and targeted-conjugated magnetic NPs with $22.9 \pm 4.8 \mathrm{~nm}$ diameter, respectively [24]. However, they did not report the exact MR acquisition time point, which we believe is crucial for tumor imaging, especially for magnetic NPs.

Our study also has some limitations. First, by 2 weeks after injection of ovarian cancer cells into the peritoneal cavity, the tumors often had become large (average diameter about $5 \mathrm{~mm}$ ) with isointensity signals on $\mathrm{T}_{2}$-weighted MR imaging making them easily detectable and distinct from surrounding tissues, which had mostly hyperintensity signals. However, tumors at an earlier stage or smaller might not be detected because of overlapping neighboring organs (such as gut, kidney, or bladder) and background tissues. Perhaps the specificity and sensitivity could be improved by the use of bimodal magnetic nanoprobes with fluorescent materials incorporated into $\mathrm{Fe}_{3} \mathrm{O}_{4}$ NPs. Second, since FA receptors are overexpressed in most malignant tumors, the FA targeting ligand we used may not be specific for detecting ovarian cancer. Further studies should be conducted to image ovarian cancer with targeting motifs that may be more specific.

\section{Conclusion}

In summary, this study demonstrated that the prepared FA-targeted $\mathrm{Fe}_{3} \mathrm{O}_{4}$ NPs can bound specifically in vitro to the FA receptors overexpressed human serous ovarian cells without inducing cytotoxicity. Used as $\mathrm{T}_{2}$-negative contrast agents in MR imaging, the particles also localized to intraperitoneal human ovarian cancer tissues in a xenograft tumor model. Importantly, the tumor can be detected more obviously after the mice were injected with FA-targeted $\mathrm{Fe}_{3} \mathrm{O}_{4}$ NPs than non-targeted $\mathrm{Fe}_{3} \mathrm{O}_{4}$ NPs. Thus, FA-targeted $\mathrm{Fe}_{3} \mathrm{O}_{4}$ NPs hold promise that they may be multifunctional nanoprobes for the diagnosis and treatment of ovarian cancer.

\section{Ethics approval}

All the animal experiments were performed according to protocols approved by the Ethical Committee of Obstetrics and Gynecology Hospital ([2007]-No. 6), Fudan University.

\section{Consent for publication}

Not applicable.

\section{Abbreviations \\ DMSO: dimethyl sulfoxide; EPR: enhanced permeability and retention; FA: folic acid; FBS: fetal bovine serum.; $\mathrm{Fe}_{3} \mathrm{O}_{4}$ : iron oxide; ICP-OES: Leeman prodigy inductively coupled plasma-optical emission spectroscopy; MR: magnetic resonance; MTT: 3-(4,5-dimethylthiazol-2-yl)-2,5-diphenyltetrazolium bromide; NPS: nanoparticles; PBS: phosphate-buffered saline; PEG: polyethylene glycol; PEl: polyethyleneimine; TEM: transmission electron microscopy.}

\section{Competing interest}

The authors declare that they have no competing interest.

\section{Authors' contributions}

XS, MS and GZ designed of the whole study; $H Z$, JL and $Y H$ performed the experiments and analyzed the data; $\mathrm{HZ}$, JL wrote and revised the manuscript finally. All authors read and approved the final manuscript.

\section{Acknowledgements}

This research is financially supported by the Fund of the Science and Technology Commission of Shanghai Municipality (12520705500), the Sino-German Center for Research Promotion (GZ899), and the Program for Professor of Special Appointment (Eastern Scholar) at Shanghai Institutions of Higher Learning.

Received: 3 February 2016 Accepted: 18 March 2016

Published online: 29 March 2016

References

1. Moyle P, Addley HC, Sala E. Radiological staging of ovarian carcinoma. Semin Ultrasound CT MR. 2010;31:388-98.

2. Sato $\mathrm{S}$, Itamochi H. Bevacizumab and ovarian cancer. Curr Opin Obstet Gynecol. 2012;24:8-13.

3. Ozols R, Bookman M, Connolly D, et al. Focus on epithelial ovarian cancer. Cancer Cell. 2004:5:19-24.

4. Vencken $P$, Kriege $M$, Hoogwerf $D$, Beugelink S, van der Burg M, Hooning M Chemosensitivity and outcome of BRCA1- and BRCA2-associated ovarian cancer patients after first-line chemotherapy compared with sporadic ovarian cancer patients. Ann Oncol. 2011:22:1346-52.

5. Morgan R, Alvarez R, Armstrong D, et al. Ovarian cancer, version 3.2012. J Natl Compr Canc Netw. 2012;10:1339-49.

6. Konner JA, Grabon DM, Gerst SR, et al. Phase II study of intraperitoneal paclitaxel plus cisplatin and intravenous paclitaxel plus bevacizumab as adjuvant treatment of optimal stage II/III epithelial ovarian cancer. J Clin Oncol. 2011;29:4662-8

7. Yamashita Y, Torashima M, Hatanaka Y, et al. Adnexal masses: accuracy of characterization with transvaginal US and precontrast and postcontrast MR imaging. Radiology. 1995;194:557-65.

8. Hricak H, Chen M, Coakley FV, et al. Complex adnexal masses: detection and characterization with MR imaging-multivariate analysis. Radiology. 2000;214:39-46. 
9. Zhang H, Zhang G-F, He Z-Y, Li Z-Y, Zhang G-X. Prospective evaluation of 3T MRI findings for primary adnexal lesions and comparison with the final histological diagnosis. Arch Gynecol Obstet. 2014;289:357-64.

10. Yang $H$, Zhuang $Y$, Sun $Y$, et al. Targeted dual-contrast $T_{1}$ - and $T_{2}$-weighted magnetic resonance imaging of tumors using multifunctional gadoliniumlabeled superparamagnetic iron oxide nanoparticles. Biomaterials. 2011;32: 4584-93.

11. Wen S, Li K, Cai H, et al. Multifunctional dendrimer-entrapped gold nanoparticles for dual mode CT/MR imaging applications. Biomaterials. 2013;34:1570-80.

12. Shi $X$, Wang SH, Swanson SD, et al. Dendrimer-functionalized shellcrosslinked iron oxide nanoparticles for in-vivo magnetic resonance imaging of tumors. Adv Mater. 2008;20:1671-8.

13. Xie J, Xu C, Kohler N, Hou Y, Sun S. Controlled PEGylation of monodisperse $\mathrm{Fe}_{3} \mathrm{O}_{4}$ nanoparticles for reduced non-specific uptake by macrophage cells. Adv Mater. 2007;19:3163-6.

14. Zhang H, Li J, Sun W, Hu Y, Zhang G, Shen M, Shi X. Hyaluronic acidmodified magnetic iron oxide nanoparticles for MR imaging of surgically induced endometriosis model in rats. PLoS One. 2014:9:e94718.

15. Shao HMC, Issadore D, Liong M, Yoon TJ, Weissleder R, Lee H. Magnetic nanoparticles and microNMR for diagnostic applications. Theranostics. 2012;2:55-65

16. Hayashi KNM, Sakamoto W, Yogo T, Miki H, Ozaki S, Abe M, Matsumoto T, Ishimura K. Superparamagnetic nanoparticle clusters for cancer theranostics combining magnetic resonance imaging and hyperthermia treatment. Theranostics. 2013;3:366-76.

17. Lee $N$, Choi $Y$, Lee $Y$, et al. Water-dispersible ferrimagnetic iron oxide nanocubes with extremely high $r_{2}$ relaxivity for highly sensitive in vivo MRI of tumors. Nano Lett. 2012;12:3127-31.

18. Xu C, Sun S. Superparamagnetic nanoparticles as targeted probes for diagnostic and therapeutic applications. Dalton Trans. 2009;29:5583-91.

19. Sega E, Low P. Tumor detection using folate receptor-targeted imaging agents. Cancer Metastasis Rev. 2008;27:655-64

20. Low PS, Kularatne SA. Folate-targeted therapeutic and imaging agents for cancer. Curr Opin Chem Biol. 2009;13:256-62.

21. Li J, Zheng L, Cai H, et al. Polyethyleneimine-mediated synthesis of folic acid-targeted iron oxide nanoparticles for in vivo tumor MR imaging. Biomaterials. 2013:34:8382-92.

22. Chen $\mathrm{Q}$, Li K, Wen S, et al. Targeted CT/MR dual mode imaging of tumors using multifunctional dendrimer-entrapped gold nanoparticles. Biomaterials. 2013;34:5200-9.

23. Li J, Hu Y, Yang J, et al. Facile synthesis of folic acid-functionalized iron oxide nanoparticles with ultrahigh relaxivity for targeted tumor MR imaging J Mater Chem B. 2015;3:5720-30.

24. Satpathy $M$, Wang $L$, Zielinski $R$, et al. Active targeting using HER-2-affibodyconjugated nanoparticles enabled sensitive and specific imaging of orthotopic HER-2 positive ovarian tumors. Small. 2014:10:544-55.

25. Hensley NAR HH, O'Brien SW, Bickel LE, Fang X, Sam L, Connolly DC. Combined in vivo molecular and anatomic imaging for detection of ovarian carcinoma-associated protease activity and integrin expression in mice. Neoplasia. 2012;14:451-62.

26. Zhang $X$, Chen J, Kang $Y$, et al. Targeted paclitaxel nanoparticles modified with follicle-stimulating hormone $\beta$ 81-95 peptide show effective antitumor activity against ovarian carcinoma. Int J Pharm. 2013;453:498-505.

27. X-y Z. Chen J, Zheng Y-f, et al. Follicle-stimulating hormone peptide can facilitate paclitaxel nanoparticles to target ovarian carcinoma in vivo. Cancer Res. 2009;69:6506-14

28. Gallo J, Long NJ, Aboagye EO. Magnetic nanoparticles as contrast agents in the diagnosis and treatment of cancer. Chem Soc Rev. 2013;42:7816-33.

29. Berry CC, Wells S, Charles S, Aitchison G, Curtis ASG. Cell response to dextran-derivatised iron oxide nanoparticles post internalisation. Biomaterials. 2004;25:5405-13.

30. Larsen EKU, Nielsen T, Wittenborn T, et al. Size-dependent accumulation of PEGylated silane-coated magnetic iron oxide nanoparticles in murine tumors. ACS Nano. 2009;3:1947-51.

31. Chertok B, David AE, Yang VC. Polyethyleneimine-modified iron oxide nanoparticles for brain tumor drug delivery using magnetic targeting and intra-carotid administration. Biomaterials. 2010:31:6317-24.

32. Turcheniuk K, Tarasevych AV, Kukhar VP, Boukherroub R, Szunerits S. Recent advances in surface chemistry strategies for the fabrication of functional iron oxide based magnetic nanoparticles. Nanoscale. 2013;5:10729-52.
33. Hao R, Yu J, Ge Z, et al. Developing $\mathrm{Fe}_{3} \mathrm{O}_{4}$ nanoparticles into an efficient multimodality imaging and therapeutic probe. Nanoscale. 2013;5:11954-63.

34. Yen SKPP, Selvan ST. Multifunctional iron oxide nanoparticles for diagnostics, therapy and macromolecule delivery. Theranostics. 2013;3:986-1003.

35. Gupta AK, Gupta M. Synthesis and surface engineering of iron oxide nanoparticles for biomedical applications. Biomaterials. 2005;26:3995-4021.

36. Li J, He Y, Sun W, et al. Hyaluronic acid-modified hydrothermally synthesized iron oxide nanoparticles for targeted tumor MR imaging. Biomaterials. 2014;35:3666-77.

37. Li J, Zheng L, Cai $\mathrm{H}_{\text {, et }}$ al. Facile one-pot synthesis of $\mathrm{Fe}_{3} \mathrm{O}_{4} @ A u$ composite nanoparticles for dual-mode MR/CT imaging applications. ACS Appl Mater Interfaces. 2013;5:10357-66.

38. Pan B, Cui D, Sheng Y, et al. Dendrimer-modified magnetic nanoparticles enhance efficiency of gene delivery system. Cancer Res. 2007;67:8156-63.

39. Jiang G, Park K, Kim J, et al. Hyaluronic acid-polyethyleneimine conjugate for target specific intracellular delivery of siRNA. Biopolymers. 2008;89:635-42.

40. Cai $H, A n X, C u i J$, et al. Facile hydrothermal synthesis and surface functionalization of polyethyleneimine-coated iron oxide nanoparticles for biomedical applications. ACS Appl Mater Interfaces. 2013;5:1722-31.

41. Chen WW, Ruiz B, Killeen JL, et al. Pathology and classification of ovarian tumors. Cancer. 2003;97:2631-42.

42. Zhang J, Chen $X$, Shi $G$, et al. Establishment of a new representative model of human ovarian cancer in mice. J Ovarian Res. 2013;6:9.

43. Quinn B, Xiao F, Bickel L, et al. Development of a syngeneic mouse model of epithelial ovarian cancer. J Ovarian Res. 2010;3:24.

44. Bankert RBB-IS, Odunsi K, Shultz LD, Kelleher Jr RJ, et al. Humanized mouse model of ovarian cancer recapitulates patient solid tumor progression, ascites formation, and metastasis. PLoS One. 2011;6:e24420.

45. Hensley H, Quinn BA, Wolf RL, et al. Magnetic resonance imaging for detection and determination of tumor volume in a genetically engineered mouse model of ovarian cancer. Cancer Biol Ther. 2007:6:1717-25.

\section{Submit your next manuscript to BioMed Central and we will help you at every step:}

- We accept pre-submission inquiries

- Our selector tool helps you to find the most relevant journal

- We provide round the clock customer support

- Convenient online submission

- Thorough peer review

- Inclusion in PubMed and all major indexing services

- Maximum visibility for your research

Submit your manuscript at www.biomedcentral.com/submit
) Biomed Central 